\title{
Relation Between the Histogenesis of the Wolffian Body and the Differentiation of Blood Cells in Chick Embryos
}

\author{
By \\ Kikuo Chishima \\ (Dept. of Vet. Med. The Gifu Univ. Gifu-Ken, Japan.) \\ Six Figures

\section{Introduction}

Ever since wolffian body was first described by Wolff (1890) it has been generally believed by many workers (Brambell, '28, Lillie, '19 and others) that the glomeruli and Wolffian tubules begin their develepment as a result of the condensation and mitotic proliferation of mesenchymal cells. However it ceems probable that this conception may demand further comprehensive evidence, because the most important problem with regard to the source or origin of these elements has not yet been settled so far as the writer is aware. It is widely accepted opinion that the erythrocytes are the most highly differentiated cells and so I can find no paper dealing with the behavior and differential potencies of erythrocytes, even though there have been published tremendous amount of the literatures regarding to erythrocytes.

The writer (Chishima $(2-14,29)$; have reported that the erythrocytes in several species of vertebrates show wonderful behavior and they may have very wide differentiating capacities. This paper is a description of the relation between the histogenesis of Wolffian body and the differentiation of the blood cells in chick embryos.

\section{Acknowledgements}

This study was carried out during the years 1940-1944 at the Kyushu University. I wish to express my gratitude to Professor Masaharu Tange for his helpful advice ahd criticism. My thanks 
are also due professor Hajime Mimura for his suggestion and counsel.

\section{(I) Materials and Methods}

$257 F_{1}$ chick embryos obtained by crossing female Barred Plymouth Rock with male Rhole Island Red which were kept at the Laboratory of Zootechny, Dept. of Agriculture, Kyushu University were used as materials. Age of embryos ranged from 4 days to 21 days of incubation. As a fixative Bouin's fluid was used, and serial sections were cut 4 to 10 micra thick, stained with Delaf ield's hematoxylin and eosin, in some instances Flemming, Champy, Meves, Regaud and Allen Bouin's fluid were used as fixatives. Hydrogen Peroxyde, which was diluted with equal amount of Ringer's solution, were injected into the air chamber of some of incubating eggs, and then at certain days after the operation the Wolffiian bodies were examined.

The Wolffian bodies removed from embryos at 9-10 days of incubation, transplanted into the collio-allantoic cavities of the other incubating eggs at the same age through the small whole which had been made on the egg shell. The operated eggs returned to incubator, and after certain interval the transplanted tissues were studied microscopically.

\section{Results}

(a) Direction and Phases of the Differentiation of the Blood Cells in Wolffian body.

The embryonic erythrocytes (IA) migrated into wolffian body show the transitional phases into following four main directions, namely, IIA. IIB. IIC. and IID under the influence of induction of field at which the erythrocytes are lozated and then these four types of cells further show, transitional phases into III A. III B. III. C. and III D. respactively, according to lapse of time.

Thus all of elements of wolffian body in chick embryo belong to any one of these four phases. These classification of the cell types, however, are only for the convenience sake of studies, so that, in strict sense, it is unable to draw a strict line among these cell-types because they show continual or transitional phases in each other.

The characteristics of the cell-types described above are as follows :-

PHASE I. The embryonic erythrocytes belong to this type, and this type may further be subdivided into two types I A and I B. 
TYPE I A. Round or oval normal embryonic erythrocytes, about 6 by 13 micra in size, belong to this type. But the erythrocytes at more later embryonic stages in incubation become more ellipsoidal and smaller in shape.

Type I A-cells have relatively small, basophilic, oval or round nuclei including a few chromatin granules and have eosinophilic cytoplasm of somewhat mottled appearance.

TYPE IB. The erythrocytes belonging to this type are more eliptical in form than IA and often show irregular outline of cells. The cytoplasm is characterized with two distinct zones, the inner zone surrounding the nucleus stained more intensely than the outer zone. So that it appears, as if, it represents a result of plasmolysis.

Type I B. perhaps is older stage than type I A, but this conception may need further investigation.

PHASE JI. This phase includes the type II A. II. B. II. C. and II D. and each of them shows transittonal phase from phase $I$.

These four main directions of differnntiation in embryonic erythrocytes may be attributed to their localization in wolffian body and to the inductions of each fields.

Type II A. The cells belonging to this type exist most commonly in interstitial lumen of Wolffian body, and show transitional phases from type I A cells. Scanty, clear cytoplasm, relatively large round mucleus occupying nearly the whole cell body, are characteristic to the cells of this type. The inner structure of the nuclei of this type is characterized with the presence of dense, large, irregular and dark staining clumps of basochromatins. Within these clumps there are narrow clear spaces. The arrangement of the chromatin particle resembling to a form of spokes of wheel, as often being mentioned as a characteristic feature of lymphocyte, is by no means common to this type. Above-described feature is of the younger stage of type II A-cell and is not essentially different from the small lymphocytes. However, according to advancement of differentiation, they become somewhat resembling to middle-size-lymphocytes bearing larger, lighter nuclei and slightly increased clear protoplasm. (Fig. 3, 4)

Type II B. (Fat-laden cell-like) (Fig. 3.)

Type II. B. cells, show also all of transitional phases from the type I A ; however, contains no oxy-hemoglobin, therefore cytoplasm appears as clear as that of "fat-laden cell" which is found in embryonic gonad.

The outline of the cell is somewhat polyedral, owing to mutual pressure. The surface of nucleus, situated eccentrically, is somewhat 
K. Chishima.

obscure and protrudes many of fine nuclear strands toward the cyto. plasm. This type of cell may be seen in the inner part of glomeruli. Type II C. (fibroblast or connective tissue cell-kike) (Fig. 4)

This type also shows every transitional form from type I A and is essentially identical in structure of nucleus and cytoplasm to type II A, but differs in form, that is to say, both of nucleus and cytoplasm are. elongated and spindle-kike in shape. The spatial site, where this direction of differentiation occurs, is a very narrow space of the surface of tissue or organ, such as the outer surface of Wolffian body, wolffian tubules or of glomeruli.

TYPE II D (Eosinophilic granulocytes)

This group of cells takes its appearance, at first, in the intertubular lumen ot Wolffian body in chick ambryo at about 14 days of incuba. tion, but still there can, at that time, be seen no eosinophilic granulocytes in circulating blood. These cells are, most probably, dérived from type I A and IB. The cytoplasm of these cells stains deeper red than normal erythrocytes, and includes intensely staining eosinophilic granules in it. There can be seen complete series of transitions from the eosinophilic granulocytes with abundant granules to that with very few of granules.

- PHASE III (Mesenchymatous Cells)

This phase includes type III A, IIJ B, III C and III D, and each of them shows transitional phases, from II A, II. B, II C and II D, respectively, but these four types resemble to one another. (Fig. 3)

These four cell-types have usually, round or oval but semetimes polymorphous, so that they are variable in size and form. Slightly basophilic cytoplasm is often accumulated on the one side of nucleus The nucleus is larger, vesicular and stains lighter than that of type II A, so that this cell-type is identical in essential points to so-called mesenchyme cell. However, some of them situating at periphery of glomeruli, are larger in size and are multinucleated.

These multimecleated cells does not seems to be a resultant of amitosis; but they may be referred to a syncytium, and they often show transition to degenerating form. The existence of above mentioned diffrentiating direction and transitional phases in embryonic erythroytes may further be substantiated by the following facts:-

(b) The Histogenesis of Glomeruli in Connection with the Differentiation of Erythrocytes in Chick Embryo.

Development of Wolffian body begins by condensation of mesone. phric elements; mesenchymatous elements, at first, but these mesenchy- 
matous elements show every transitional phases from erythrocytes which have migrated into the lumen of Wolffian body through the mesonephric artery. Most of the newly formed glomerulis, in the early embryonic stage at 4 to 7 days of incubation, consist chiefly of erythrocytes (Type I A), however, the erythrocytes gradually decrease in number, thence-forth, on the other hand, phases II or III cells, increase in number, and some of glomeruli become at last consisted almost entirely of the phase II cells. Thus there can be seen every transitional phases from erythrocytes into mesenchymatous components. (Phase III cells) within Wolffian body. The erythrocytes included in a glomerulus are usually more deeply stained with eosin than those in intertubular lumen. At the early embryonic stage (4-5 days) most of glomeruli lie on the upper and inner boundary: of Wolffian body, the nearest place to the dorsal aorta. And there can often be seen the newly formed anlage of glomerulus which is composed of the glomeration of about thirty to fifty erythrocytes connecting with dorsal aorta through small capillaries. (Fig. 1-4)

New formation of glomeruli continues until the later stage at about 14-15 days of incubation. At that tage, some of the large Primordial glomeruli are often composed of 200-300 erythrocytes but then they become separated into five or more clumps. These erythrocytic clumps also show transitional phases into glomeruli. The sign of degeneration of glomeruli begines at later stage by taking appearance of older type of phase IIJ. cells on the surface of glomeruli. The older type of phase III cells with large vesicular nuclei or sometimes with polynuclei, isolate themselves from the surface of glomeruli and then they degenerate.

The so-called mensonephros tissue cells which are hither-to believed to be a source of the histogenesis of Wolffian body, may most probably, correspond to type II A cells or younger stage of phase III cells at the very early embryonic stage. This opinion may be supported by the fact that there can be seen extravascular erythrocytes scattered every.where in the Wolffian body and they are almost always mingled with mesenchymatous cells which show the transition from erythrocytes.

Furthermore, in spite of vast increase in number of the components of glomeruli there can be recognizable very scarce mitotic figures. (Table 1) (Fig. 3, 4)

(c) Histogenesis of Wolffian Tubules.

The Wolffian tubules begin also their formation by the condensation of so-called mesonephrous elements of embryos at 3 to 4 days of incubation. But since that embryonic age there arise the clumped masses of 
erythrocytes which then show transitional phases into the mass of mesonephrous elements mentioned above. (Fig. 5) In the center of these spheroid cell masses, appear then clear lumen, and the tubular structure may be completed by anastomosis or fusing together with these cell masses lying closely side by side. The source of the elements of wolffian tubules also may be referred to erythrocytes, because there are transitional phases between these two kinds of elements, and the mitotic indices of the mesonephrous tissue cells are very low value.

The basophilic properties of the elements of Wolffian tubules at early stage of the tubular formation, have become eosinophilic according to the advance of the tubular age, and at last degenerate reducing their staining capacity. Thus we can discriminate the eosinophilic tubules from basophilic tubules of a Woffian body in chick embryo at 7 days of incubation or at still older one. It is not uncommon that the type IIC bells adhering on the outer surface of W.t. show transition, on the one hand, to the erythrocytes, and on the other to the cells composing $\mathrm{W}$. tubules. The formation and development of W.t. in chick embryo do not cease on the 10th to 11th day of incubation as has been believed, but continue at 14-15 days of incubation in male embryos or at 15-17 days of incubation in femals embryos. The epithelial cells covering the surface of Wolffian body degenerate periodically; the first appears during 7-10 days of incubation and the second takes place during 14-21 days of incubation. As a result of that phenomenon, the intertubular blood cells flow out on the surface of Wolffian body, and they form a blood layer on the surfnce so that the blood layer attains sometimes about 20-40 micra in thick. (Fig. 6) The erythrocytes localized in the outer most of this layer show transition into type II C cells and at last into phase III cells.

(d) Some of Experimental Results as to the Differentiation of Erythrocytes in Wolffian Body.

Diluted hydrogen peroxyed solution has been brought by injection into the air chamber of egg at 13-15 days of incubation. After 2-3 days of the injection the mesonephros was dissected from embryo and examined. The Wolffian body of chick embryo, which has died suffering from mesonephritis caused by the injection, showed follow. ing symptom of servere inflammation viz., the increase in size of mesonephros about four to five times larger than normal one, new formation of large blood vessels on its surface and turning to brilliant pink or chocolate color in fresh condition. The serial sections of above described mesonephros were inspected under microscope. 
Table 1. Mitotic index* in the mesonephros in the chick embryos.

\begin{tabular}{|c|c|c|c|c|c|c|c|c|c|c|}
\hline \multirow{2}{*}{$\begin{array}{l}\text { Age of emb. in } \\
\text { days \& sex }\end{array}$} & \multirow{2}{*}{$\begin{array}{l}\text { No. of } \\
\text { emb. }\end{array}$} & \multicolumn{3}{|c|}{ Glomeruli } & \multicolumn{3}{|c|}{ Wolffian tubules } & \multicolumn{3}{|c|}{ Intertubular cell } \\
\hline & & * a & $\mathbf{b}$ & c & a & $\mathbf{b}$ & c & a & $\mathrm{b}$ & c \\
\hline 3 & 2 & 637 & 3 & 0.470 & 253 & 4 & 1581 & 220 & 2 & 0.909 \\
\hline 3.5 & 2 & 358 & 2 & 0.559 & 204 & 2 & 0.980 & 211 & 5 & 2.370 \\
\hline 4 & 2 & $\subsetneq 90$ & 6 & 1.539 & 232 & 3 & 1.293 & 242 & 7 & 2.892 \\
\hline 5 & 6 & 1512 & 7 & 0.463 & 1103 & 23 & 2.085 & 1171 & 12 & 1.024 \\
\hline 6 & 5 & 992 & 5 & 0.504 & 875 & 8 & 0.913 & 458 & 7 & 1.528 \\
\hline 7 & $\begin{array}{l}2 \\
2\end{array}$ & $\begin{array}{l}273 \\
804\end{array}$ & $\begin{array}{l}3 \\
4 \\
\end{array}$ & $\begin{array}{l}1099 \\
0.498\end{array}$ & $\begin{array}{l}294 \\
510\end{array}$ & $\begin{array}{l}4 \\
8\end{array}$ & $\begin{array}{l}1.361 \\
1.568\end{array}$ & $\begin{array}{l}505 \\
502\end{array}$ & $\begin{array}{l}3 \\
8\end{array}$ & $\begin{array}{l}0.594 \\
1.594\end{array}$ \\
\hline 8 & $\begin{array}{l}3 \\
1\end{array}$ & $\begin{array}{r}1012 \\
450\end{array}$ & $\begin{array}{l}5 \\
1\end{array}$ & $\begin{array}{l}0.494 \\
0.222\end{array}$ & $\begin{array}{r}1003 \\
453\end{array}$ & $\begin{array}{l}7 \\
2\end{array}$ & $\begin{array}{l}0.698 \\
0.442\end{array}$ & $\begin{array}{r}1210 \\
450 \\
\end{array}$ & $\begin{array}{r}11 \\
2\end{array}$ & $\begin{array}{l}0.909 \\
0.444\end{array}$ \\
\hline 9 & $\begin{array}{l}1 \\
1\end{array}$ & $\begin{array}{r}187 \\
800\end{array}$ & $\begin{array}{l}1 \\
1\end{array}$ & $\begin{array}{l}0.535 \\
0.500 \\
\end{array}$ & $\begin{array}{l}221 \\
213 \\
\end{array}$ & $\begin{array}{l}2 \\
2 \\
\end{array}$ & $\begin{array}{l}0.904 \\
0.939 \\
\end{array}$ & $\begin{array}{l}263 \\
325 \\
\end{array}$ & $\begin{array}{l}1 \\
2\end{array}$ & $\begin{array}{l}0.380 \\
0.615\end{array}$ \\
\hline 10 & $\begin{array}{l}2 \\
2 \\
\end{array}$ & $\begin{array}{l}612 \\
953 \\
\end{array}$ & $\begin{array}{l}3 \\
3 \\
\end{array}$ & $\begin{array}{l}0.490 \\
0.315\end{array}$ & $\begin{array}{l}675 \\
818\end{array}$ & $\begin{array}{l}3 \\
3\end{array}$ & $\begin{array}{l}0.444 \\
0.367\end{array}$ & $\begin{array}{l}568 \\
732\end{array}$ & $\begin{array}{l}3 \\
5\end{array}$ & $\begin{array}{l}0.528 \\
0683\end{array}$ \\
\hline 11 & $\begin{array}{l}2 \\
1\end{array}$ & $\begin{array}{l}950 \\
506\end{array}$ & $\begin{array}{l}2 \\
2 \\
\end{array}$ & $\begin{array}{l}0.211 \\
0.395 \\
\end{array}$ & $\begin{array}{r}1053 \\
601 \\
\end{array}$ & $\begin{array}{l}3 \\
2 \\
\end{array}$ & $\begin{array}{l}0.285 \\
0.333 \\
\end{array}$ & $\begin{array}{l}330^{-} \\
315 \\
\end{array}$ & $\begin{array}{l}2 \\
1 \\
\end{array}$ & $\begin{array}{l}0.606 \\
0.317 \\
\end{array}$ \\
\hline 12 & 1 & 411 & 1 & 0.243 & 502 & 1 & 0.199 & 297 & 1 & 0.337 \\
\hline 13 & $\begin{array}{l}2 \\
4 \\
\end{array}$ & $\begin{array}{l}1105 \\
2207\end{array}$ & $\begin{array}{l}2 \\
5\end{array}$ & $\begin{array}{l}0.181 \\
0.227\end{array}$ & $\begin{array}{r}970 \\
2853\end{array}$ & $\begin{array}{l}2 \\
5\end{array}$ & $\begin{array}{l}0.206 \\
0.175\end{array}$ & $\begin{array}{l}\overline{\epsilon 22} \\
941\end{array}$ & $\begin{array}{l}2 \\
3\end{array}$ & $\begin{array}{l}0.322 \\
0.319\end{array}$ \\
\hline 14 & $\begin{array}{l}1 \\
2\end{array}$ & $\begin{array}{r}582 \\
1085\end{array}$ & $\begin{array}{l}1 \\
2\end{array}$ & $\begin{array}{l}0.172 \\
0.184\end{array}$ & $\begin{array}{r}593 \\
1200\end{array}$ & $\begin{array}{l}3 \\
3\end{array}$ & $\begin{array}{r}0.506 \\
0.250\end{array}$ & $\begin{array}{l}208 \\
486\end{array}$ & $\frac{u}{2}$ & $\begin{array}{l}0.481 \\
0.412\end{array}$ \\
\hline 15 & $\begin{array}{l}1 \\
1\end{array}$ & $\begin{array}{l}611 \\
600 \\
\end{array}$ & $\begin{array}{l}0 \\
1\end{array}$ & $\begin{array}{r}0 \\
0.168 \\
\end{array}$ & $\begin{array}{r}633 \\
-702 \\
\end{array}$ & $\begin{array}{l}1 \\
3 \\
\end{array}$ & $\begin{array}{l}0.158 \\
0.427\end{array}$ & $\begin{array}{l}203 \\
273 \\
\end{array}$ & $\begin{array}{l}1 \\
1\end{array}$ & $\begin{array}{l}0.493 \\
0.366\end{array}$ \\
\hline 16 & $\overline{1}$ & $\overrightarrow{851}$ & $\overline{0}$ & -0 & $\overline{809}$ & $\overline{0}$ & -0 & $\overline{535}$ & $\overline{1}$ & $\overline{0.187}$ \\
\hline 17 & $\overline{1}$ & $\overrightarrow{753}$ & $\overline{1}$ & $0 . \overline{133}$ & $\overline{717}$ & $\overline{2}$ & $\overline{0.279}$ & $\overline{231}$ & $\overline{1}$ & $\overline{0.433}$ \\
\hline 18 & $\begin{array}{l}1 \\
4 \\
\end{array}$ & $\begin{array}{r}500 \\
2753\end{array}$ & $\begin{array}{l}0 \\
1\end{array}$ & $\begin{array}{r}0 \\
0.036\end{array}$ & $\begin{array}{r}511 \\
2620 \\
\end{array}$ & $\begin{array}{l}0 \\
2 \\
\end{array}$ & $\begin{array}{r}0 \\
0.079\end{array}$ & $\begin{array}{l}247 \\
853\end{array}$ & $\begin{array}{l}0 \\
1\end{array}$ & $\begin{array}{r}0 \\
0.012\end{array}$ \\
\hline 21 & $\begin{array}{l}3 \\
5\end{array}$ & $\begin{array}{l}1418 \\
2788\end{array}$ & $\begin{array}{l}4 \\
3 \\
\end{array}$ & $\begin{array}{l}0.282 \\
0.108\end{array}$ & $\begin{array}{l}172 \overline{4} \\
2812\end{array}$ & $\begin{array}{l}1 \\
1\end{array}$ & $\begin{array}{l}0.058 \\
0036\end{array}$ & $\begin{array}{r}895 \\
1217 \\
\end{array}$ & $\begin{array}{l}1 \\
1\end{array}$ & $\begin{array}{l}0.116 \\
0.082\end{array}$ \\
\hline
\end{tabular}

* a........ No. of cells in resting in certain field.

b........ No. of cells in mitosis in the same field.

c........ Mitotic index which were culculated as follows :

$$
\frac{M}{C} \times 100
$$

$M$, represents the numbers of dividing cells countered, and

$C$, the numbers of resting cells found in the same areas. 
The intertubular sinusoid were filled with abundant erythrocytes, thus the walls of Wolffian tubules have been pressed by the erythrocytes and sometimes they atrophied so severely that the whole mesonephros appears as if a sac filled with blood. Sections were made of the mesonephros of chick embryo which were allowed to set on incubator for 2 days after they had died with artificial mesodephritis. In these sections the intertubular lumens or sinusoid were filled with small lymphoid cells, on the contrary, there could not be seen any of nomal erythrocytes or their degenerative forms, and moreover there were transitional phases from erythrocytes to the small lymphoid cells. So, the writer was compelled to have a conception that these lymphoid elements originated from the differentiation of the erythrocytes in situ.

Sometimes I have examined the mesonephric sections which have made from dead embryos which were allowed to set on the incubator for 2 to 3 days after they had died suffering from artifical asphixia by means of applying vaselin on the whole surface of incubating eggs. In such a section I found an interesting fact that all of mesonephroic elements showed a tendency to become uniform cell type with decreased amount of cytoplasm and reducing in staining capacities, rounding up of the outline of cell and nucleus, pycnosis of nucleus of younger cell. thus. all of mesonephoric elements became resembling to the small lymphocytes. It is of interest that there is certain relationship between the age of cells and staining properties of their nuclei, that is to say, the nuclei of young, undifferentiated cells (Phase II cell) stained more intensely with basophilic dye than that of the more advanced stage (Phase HI cell).

(e) The mitotic indices in the Mesonephros of the chick embryos show very low values. (Tab. 1 )

\section{Discussion}

Some investigators in the present time hold an opinion that every kind of cells begets its own kind of cell by mitotic division, that is to say, the muscle cells are derived only from muscle cells, epithelial cells arise from epithelial cells only, and so on, while other investigators stand against the opinion. It seems to the writer that there is a general trend of the opinions passing gradually away from the former opinion toward the latter one, because the evidences substantiating the possibility of differentiation from certain undifferentiated cells into other kinds of cells, have steadily been increasing. The writer intend to discuss this 
problem from the standpoint of view that the erythrocytes in chick embryo have differential potencies.

It is generally admitted view that the erythrocytes, in embryo or postnatal chick, are highly differentiated or senile cells when they begin their life work, and have no further differential capacities. But as far as chick embryos are concerned the writers can not agree with such opinion on account of the following facts:-

(1) Existence of transitional form.

Existence of transitional phases between erythrocytes and the elements of mesonephros as has been described in detail:

(2) Mitotic index and cell migration.

In spite of vast increase in number of the elements in developing Wolffian body the mitotic index shows so low values that the mitosis can hardly be referred to a chief means of supplying the increasing cells, if any, it may play an unimportant role. It has been believed by many authors that the mitotic index offers a usefull criterion for determining the part played in development by such process as cell migration or cell division. Schultz (28) studied the problem in relation with chick embryos of $18,33,48$ and 72 hours of incubations, according to her data the mitotic index of entire embryo of 18-20,33, 48 and 72 hours of incubation is $4.139,2.516,3.121$ and 1.763 , respectively. The duration of the period from prophase to telophase in mitosis of mesonephric elements, and the resting period have not been determined but it is said that the mitotic division of mesenchymal cells requires $67-$ 267 minutes, on the average about 180 minutes. The results of present observations show that the mitotic index of the cells of the glomeruli, Wolffian tubules, intertubular lumen and average of these three parts in chick embyos at 4-7 days of incubation was $0.820,1.444,1.526$ and 1.263 , respectively. If we referred to the time of duration of mitotic division to be 3 hours, value of mitotic index, 1.263, means that there are 10.1 cells may arise from 100 cells for 24 hours. By this proliferating rate, it may require, logically, about 8-9 days for 100 cells increase twice by mitotic division. While, according to my observations (unpublished data) the Wolffian body in the chick embryo at 7 days of incubation reaches about twice as large as that of embryos at 4 days of incubation. This fact may support my opinion that the migration of erythrocytes into Wolffian body and differentiation of them, in loco, play the most important role in histogenesis of Wolffian body. "Moreover, there are considerable large numbers of the elements of mesonephros are degenerating in the mesonephros, so that the cells pro: 
K. Chishima.

liferated by mitotic division may be insufficient even to supply the degenerating cells in mesonephros. Some of the workers assert that there is a diurnal mitotic rhythm in the bird's embryos, the writers could however, not confirmed such a fact in the Wolffian body of chick embryos sacrificed at every 1-2 hours interval in a day.

(3) Migration of erythrocytes and Mesenchymal Cells.

(i) The glomeruli of mesonephros receive the supply of blood through mesonephric artery, And there can always be seen many of extravasated erythrocytes which clumped in mass, within Bow man's capsul and they show transitional phases into the elements of glomerulis. Thus they may transform, most probably, into fixed elements, mesenchymal cells of glomeruli. (Fig. 1-2)

(ii) Wolffian Tubules. It is a view generally admitted that the new formation of Wolffian tubules ceases on the fifth day of incubation, because all of the mesonephrogenous tissue being then used up (Lillie (22) Lewis and Bremer, (21)). The writer observed, however, that the formation of Wolffian tubules at the most early stage, takes place by the condensation of so called mesonephric elements, mesenchymal elements, but these elements, also, belong to the type II A cells derived from erythrocytes. If the opinion of the previous workers is true, subsequent growth of Wolffian tubules since fifth day of incuba. tion should be accomplished by multiplication of the tubular elements, While, the new formation and growth of Wolffian tubules continue to 14-15 days of incubation notwithstanding there is very low value of mitotic index, so that the mitosis can not be considered to be a leading factor of increasing number of the tubular elements. On the other hands, there can be seen all of transitional forms between the cluster of erythrocytes migrated into intertubular lumen through vena cava interior, and the elements of the primordium of Wolffian tubules.

(iii) Intertubular lumen of the Wolffian Body (Venous sinusoid). The venous sinusoid which is connect $\in d$ with vena cava inferior contains several kinds of cells, i.e. all the transitional forms from type II A cell into type III A and III D cells. And in this sinusoid the ratio of II A cells to I A cells (erythrocytes) is higher than that of vena cava inferior. This means, perhaps, that the erythrocytes migrated there have differentiated into these elements in loco. (Fig. 5)

Some of the authors have described that the interlubular stroma of the mesonephros is the hematopoietic foci of eosinophilic granulocytes (Muckmulle and Michels '32 in teleost; Jordan (16), in proteus anguinus). Present writers also recognized the existence of eosinophilic 
granulocytes in that sinusoid in chick embryo (at 14 days of incubation) previous to the appearance of these cells in the blood stream. But there is evidence neither these cells proliferate by mitotic division nor emigrate from other site, on the contrary, there can be seen the transitional phases from erythrocy tes to these elements. Jordan (16) claims that in teleost, there can be found the transitional forms between eosinophilic granouaocytes and lymphoid cell, and the latter differentiate into former. The present writer (Chishima (9)) has already published that eosinophilic granulocytes arised from differentiation of, or from cytoplasmic extrusion of erythrocytes in tissue culture of bone marrow of young chickens. The most suitable site of eosinophilic granulocyteformation, perhaps is referred to be a place at which the blood current has stopped or stagnated.

(4) The Fate or Differentiatial Potencies of Blood Cells.

This subject has been throughly discussed or described by many authors, [(Kingsbury (19); Jordan (16-18) Frieländer (15); Rievel (26); Techow, (30), Nonidez (24): Maximow (23); Andrew and Andrew (1); Neuda (31) and others)] and the present writer (Ch is hima (2-12) ) also has published an opinion as to this problem, consequently it is omitted to discuss again this problem in this paper.

\section{Summary and Conclusion}

Studies on the histogenesis of Wolffian body and the differentation of erythrocytes in chick embryos have been carried out. The results obtzined in these studies may be summarized as follows :-

(1) Erythrocytes in the Wolffian body in chick embryo show transitional phases into the several sorts of elements of Wolffian body, such as small lymphoid cell, the cell resembling with fat-laden cell, fibroblast or connective tissue cell, eosinophilic granulocyte and mesenchymal cell.

(2) The primordium of glomeruli begins its development. by condensation of erythrocytes. but there-after the erythrocytes included in that anlage gradually decreasing in number, on the contrary, the small lymphoid cells increase in number and there can be seen transitional forms between these two elements.

(3) The development of Wolffian tubules begins, at first, by condensation of so-called nephrogenous tissue cells, but then they are formed from condensed mass of erythrocytes by means of the differentiation of erythrocytes, formation of lumen in the center of mass and 
K. Chishima:

fusing together with these masses, thus cord like tubule may be formed.

(4) Formation of Wolffian tubules of chick embryos does not cease on the 10 to 11 days of incubation, but continue to the later embryonic stage.

(5) The mitotic indices in glomeruli, Wolffian tubules and intertubular region are so small in value that mitosis can hardly be seen to be the chief factor of vast increase of cells in these tissues, on the contrary, there are many evidences that the leading factor of increasing in number of cells in developing mesonephros rests on the basis of the migration, and differentiation of erythrocytes into the fixed elements of Wolffian body.

(6) The experimental results show that the erythrocytes actually differentiate into small lymphoid cells in Wolffian bodies which were transplanted or received certain treatment.

\section{Literature Cited}

(1) Andrew, W. A. and N. V. Andrew. 1949: Lymphocytes in the normal Epidermis

- of Rat and Man Anat. Rec. 104, 2.

(2) Chishima, K., 1947: Studies on the histogenesis of the gonad and the differentiation of the blood cells in chick embryos. (with 51 figures and 10 text figures) (This paper was presented to the Kyusyu Univ. as a thesis for a doctorate. unpublished data.)

(3) Chishima, K., 1947: On the origin of the so.called primondial germ cell and the differentiation of the blood cells in chick embryos (abstract). Science (Kagaku, Japan). $18,3$.

(4) -. 1948: Studies on the histogenesis of the gonad and the differentiation of the Blood cells in chick embryos. (abstract) Animal husbandry. (Chikusan no Kenkyu. Japan). 3, 9.

(5) - . 1949: Relation between the "Cytoplasm.extrusion of erythrocytes" and the formation of blood platelets or several kinds of leucocytes in mammals. (I) Behaviour of eryshrocytes and formation of blood platelets, lymphocytes and monocytes in blood cell cultures or the blood smear preparations. (with English resume) Japanese Zool. Magazine. (Dobutsugaku Zassi) 58, 11.

(6) - , 1950 II. Formation of neutrophilic leucocytes and the "Field of leucocyteformation" in blood cell-culture or blood smear preparstions. (with English resume) ibid. 59. 1.

(7) - - 1950: On the relation between the formation of the muscular tissue and the differentiation of blood cells of Tadpole in vivo and on fixed preparation. Medicine and Biology (Igaku to Seibutsu gaku. Japan). 16, 2.

(8) -. 1950: Is blood cell concerned with heredity? Heredity (Iden, Japan). 4, 3.

(9) - 1950 : On the origin and fate of the bone marrow elements with special reference to the differentiation of erythrocytes in the chick embryos and newly hatched chicks. (Lectured at the Annual meeting of Jap. Veterinary. Sci. Associ. Apr. 1949. Tokyo, and Sept. 1951, Gifu) 
(10) - - 1950: Relation between the formation of the pigment cells, epithelial cells, macrophages, cartilage cells etc. in vivo or on the stained sections in Amphibian larvae. (with English resume) Acta Anatomica Nipponica (Kaibogaku Zassi) 25, 3 .

(11) - ., 1950: Relation between the behaviour of erythrocytes and the formation of the several kinds of the leucocytes in lower vertebrates. (Amphibia, Reptile and Fish) (with English resume) Japanese. J. Zool. Mag. 59, 6.

(12) -., The behaviour of the blood cells in the capillaries in the living Tadpole, (with English resume) ibid, 59, 5.

(13) - ., 1950: A new mode of blood cell proliferation, " the budding;" of the cytoplasm of erythrocytes in lower vertebrates. Science (Kagaku. Japan) 20, 10-11.

(Lectured on Feb. 2. 1950. at the meeting of the Zoological society of Japan. Nagoya).

(14) - 1950: The role of erythrocytes and platelets in the blood coagulation. (Lectured at Ann. meet (Osaka) of Jap. Soc. Vet. Sci., on March 26) (Now in Press).

(15) Frieländer, B., 1895: Über die Regeneration herausgeschnitten Teile des Zentralnervensystems von Regenwurmern. Zeitsehr. wiss. Zool. 60.

(16) Jordan, H.E., 1932: The histology of the blood and the bloodforming tissue of Urodel, Proteus anguineus. Amer. J. Anat. 51.

(17) -., 1937: The relation of lymphoid nodules to blood production in the bone marrow of Turkey. Anat. Rec. 68.

(18) -., The lymphocytes in relation to erythrocyte production. Anat. Rec. 76.

(19) Kingsbury, B.F., 1932: The development of the pharyngeal tonsil (cat) cell types. Amer. J. Anat. 51.

(20) Kraft, J., 1932: Vitalfarbungsversuche der Karausshenniere. Zeitschr. f. Zellforsch. u. mikr. A nat. 14.

(21) Lewis, F.T., and J.L. Bremer, 1927: A text-book of histology.

(22) Lillie, F. R., 1919: The development of the chick.

(23) Mackmul1, G. and N.A. Michels, 1932: Observation of colloidal carbon from the peritoneal cavity in the Teleost. Amer. J. Anat. 51.

(24) Maximow, A. A., 1928: Specials Cytology (Edited by Cowdry) 1.

(25) Nonidez, Z, 1920: Studies on the gonad of the fowl. Amer. J. Anat. 28.

(26) Rievel, H., 1896: Die Regeneration des Vorderarmes und endarmes bei einigen Anneliden. Zeitschr. f. wiss. Zool. 62.

(27) Richards, A., 1935: Analysis of early development of fish embryos by means of the mitotic index. I. The use of the mitotic index. Amer. J. Anat. 56.

(28) Schultz, G. 1910: The mitotic index of the chick. Proc. Okla. Acad. Sci. 2.

(29) Tange, M. and K. Chishima. 1948: On the Histogenesis of the - Woffian body and the Differentiation of the Primitive Blood cells in the Chick Embryos. (Abstract) Medicine and Biology (Igakú to Seibutsugaku) 12, 2.

(30) Techow, G., 1910: Zur Regeneration des Weichkorpers bei den Gastropoden. Arch. f. Ent. Mech. 31.

(31) Neuda, P. M., 1951: Personal Communication and "Expulsion-crescent: A new Pathological Red cell Figure in Human Peripheral Blood," Proc., Soci. Exper. Biol. and Med. 74, 1950. 


\title{
Explanation of Plate I
}

The histogenesis of Wolffian body and the differentiation of blood cells in the chick embryo.

\begin{abstract}
Abrrebiations
AO, Aorta; BC, Blood cells; Bl, Blood layer; fWT, fusing Wolffian tubules; Gl, Glomerulus; Fl-1, Glomerulus at early developmental stage of its formation; G1-2; Glomerulus at the advanced stage of its formation; Gon, Gonad; MA, Mesonephric Artery ; Mst, Mesentery ; Nch, Notochord; PWt. Primary Wolffian tubule; Vci, Vena Cave inferior; Vs, Venous sinusoid; I-A, Erythrocyte; LI-A, small lymphocyte; III-A, Mesenchymatous cell; II-B, fat-laden cell like; II-C, Fibroblast.
\end{abstract}

Fig. 1. Transverse section of 4-days chick embryo, showing the beginning of the formation of Glomerulus by the condensation of erythrocytes flowed into the lumen of Wolffian body from Aorta through the small mesonephric artery. $\times 150$.

Fig. 2. Section of 6-days-chick embryo. The relation between mesonephric artery and early histogenesis of Wolffian body are shown. $\times 135$.

Fig - 3. Section of 6-days-chick embryo. It is able to be clearly seen that the newly formed glomerulus consists of almost all of blood cells at the stages of type I-II. $\times 800$.

Fig. 4. Section of 6-days-chick embryo, indicating several differential phases of blood cells in a glomerulus and Wolffian tubules. $\times 800$.

Fig. 5. Section of 8 -days-chick embryo, the fuse of Wolffian tubules and continuity of blood in the venous sinusoid with that of vena cava inferior. $\times 150$.

Fig. 6. A part of the Wolffian body in a 14-days-chick embryo, the blood layer on the surface of Wolffian body is presented. The migrated erythrocytes have fixed there and thence.forth they differentiate into the elements of Wolffian body. $\times 800$. 

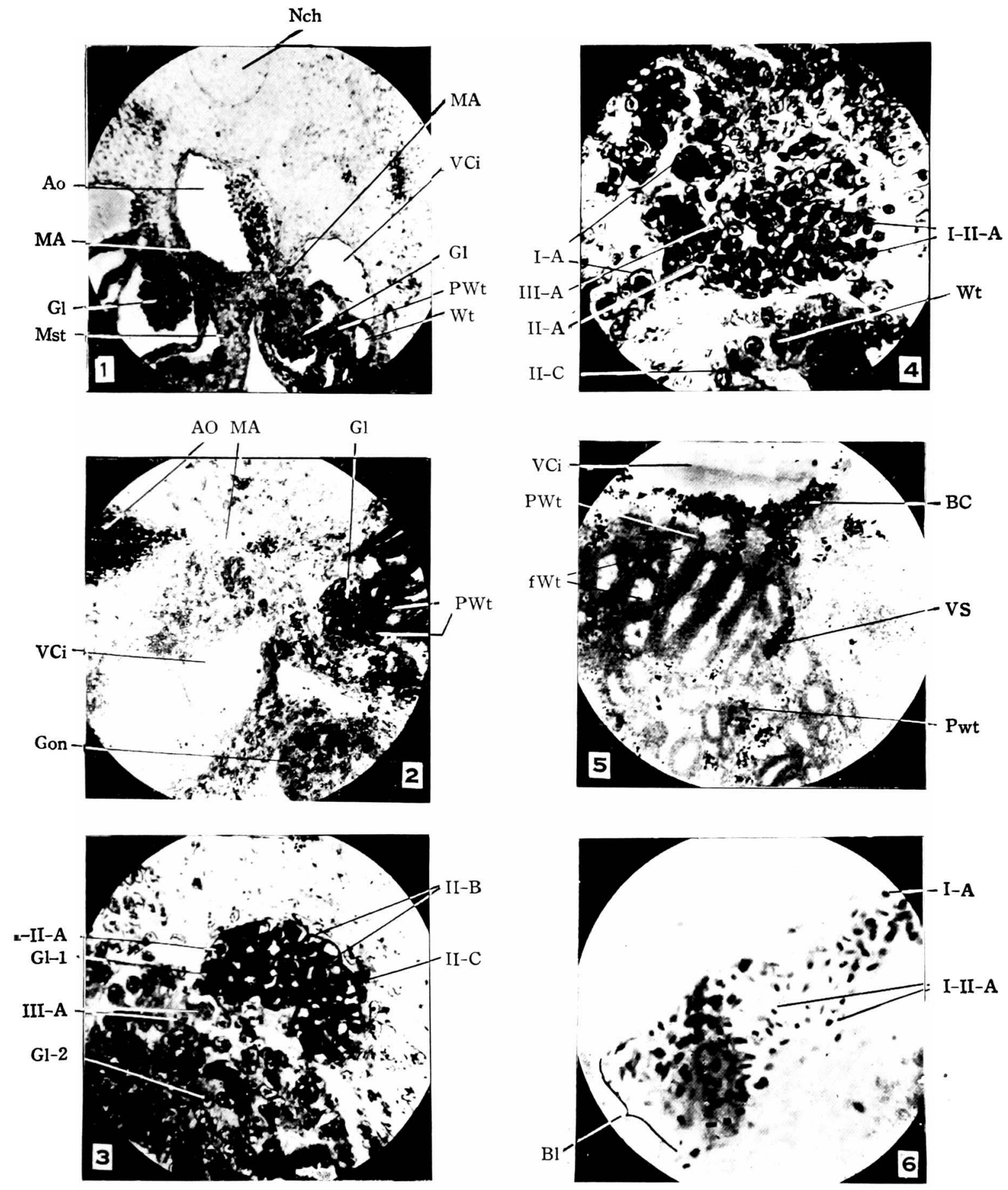